\title{
Resistencia mecánica y porosidad de soportes para pavimentos y revestimientos cerámicos obtenidos con arcillas de Castellón
}

\author{
Influence of temperature and composition in the mechanical \\ resistance and porosity of ceramic pieces
}

\author{
M.M.JORDÁN VIDAL ${ }^{\star}$, T.SANFELIUMONTOLIO** ${ }^{\star}$ C. de la FUENTE CULLELL ${ }^{\star \star \star *}$ \\ (") Univ. Miguel Hernández. Dpto. de Ciencias Experimentales y Tecnología (Alicante) \\ (“) Univ. Jaume I. Dpto. de Ciencias Experimentales (Castellón) \\ (․) Univ. de Barcelona. Dpto. de Cristalografía
}

Fecha de recepción: $28-\mathrm{I}-00$

ESPAÑA

\section{SUMMARY}

We have tried to establish a relationship between the raw material and the mechanical properties of ceramic pieces subjected to different firing processes, so under the determinant of the thermal process we have done a followup on the petrogenetic process that the manufacture of ceramics represents. This is evaluated in terms of the mechanical behaviour of the ceramic tile bodies, which have been normalised and submitted to tests for flexion. The principal objective is to be able to indicate what the optimum firing temperature for each sample is, and to determine what it is in the ceramic body which offers the greatest resistance when a specific force is applied. The study of the texture of the ceramic body will be considered mainly in relation to the existent porosity, as well as its distribution, which conditions its characteristics and specifications. The relation between porosity and the parameters that describe the porous texture of the ceramic tile pieces studied is complicated because of the fact that these have many pores with a complex and irregular spatial disposition, with a broad distribution of forms and sizes, and as such they do not fit into established empirical equations.

\section{INTRODUCCIÓN}

Para nadie es un secreto que las propiedades mecánicas de las piezas cerámicas tienen una gran importancia a la hora de determinar su utilización y aplicación para una prestación determinada (ZWEBEN, 1991). Por otra

\section{INTRODUCTION}

It is well known that mechanical properties of ceramics are of great interest when it is necessary to determine the use and application of these materials for a determined performance (ZWEBEN, 1991). On 
parte, la materia prima utilizada en la fabricación cerámica es obvio que debe tener una importante influencia sobre el comportamiento mecánico de las piezas cerámicas con ella elaborada.

WAGH et al. (1993) propuso un modelo para el estudio de la dependencia de la resistencia mecánica a la flexión con la porosidad en materiales cerámicos policristalinos. Este modelo se basa en la simplificación de considerar la microestructura de los productos cerámicos como una red continua de cilindros sólidos con canales porosos entre ellos. Las ecuaciones propuestas en el modelo son: the other hand, it is obvious that raw materials used for the manufacturing of ceramics are of large influence over the mechanical behaviour of ceramics produced from each type of raw material.

WAGH et al. (1993) proposed a model for the study of the dependency of mechanical resistance to flexion with the porosity in polycrystalline ceramic materials. This model is based on the simplification of considering the microstructure of ceramic products as a continuous network of solid cylinders with porous channels between them. The equations proposed for the model are:

$$
\begin{aligned}
& E=E_{o}(1-P)^{m}[1] \\
& \sigma_{f}=\sigma_{o}(1-P)^{m+0.5}[2]
\end{aligned}
$$

donde E, of son el módulo de Young y el de resistencia a la flexión para materiales porosos, Eo y $\sigma_{0}$ son los respectivos valores para la matriz libre de poro, $\mathrm{P}$ es la porosidad y el exponente $m$ es función de las características de los cilindros que modelizan la microestructura del sólido.

Aunque el modelo describe las formas irregulares y el tamaño de poro en los cuerpos cerámicos se pueden exponer algunas observaciones acerca de su aplicabilidad y especialmente acerca de la utilidad de esta aproximación. Las ecuaciones de este modelo tienen la ventaja de ser matemáticamente simples de manejar. Sin embargo, otras ecuaciones consideradas incluyen sólo fórmulas empíricas, simplemente consideradas por la bondad del ajuste. La comparación con los datos experimentales presenta hasta ahora, en este contexto, una excesiva dispersión para evaluación definitiva.

Una simplificación de esta ecuación puede realizarse, considerando, por ejemplo, la dependencia de la porosidad con el esfuerzo o resistencia a la fractura. Utilizando la ley de Hooke, resulta la ecuación:

$$
\varepsilon=\varepsilon_{\circ}(1-P)^{0.5}[3]
$$

La ecuación [3] predice una dependencia invariable de la resistencia mecánica con la porosidad. La pendiente de la curva resistencia mecánica-porosidad debería ser la misma para todos los productos cerámicos y estructuras porosas. Este hecho está en desacuerdo con muchos resultados experimentales.

Los estudios de DATTA et al. (1988) van dirigidos a poner de manifiesto esta discrepancia entre las previsiones teóricas y las experimentales. Estos where E, $\sigma$ represent Young's modulus and that of the resistance to flexion for porous materials, Eo and $\sigma_{0}$ are the respective values for the free pore matrix, $P$ is the porosity and the exponent $m$ is the function of the characteristics of the cylinders which model the microstructure of the solid.

Although the model describes the irregular forms and the size of the pore in the ceramic bodies, certain observations in reference to its applicability and especially in reference to the utility of this approximation can be made. The equations for this model have the advantage of being mathematically simple to work with. Other equations considered, however, include only empirical formulas, considered simply for the goodness of fit. Comparison with experimental data has so far, in this context, shown an excessive dispersion for definitive evaluation.

A simplification of this equation can be carried out, considering, for example, the dependency of the porosity with the force or resistance of the fracture. Using Hook's law, we get the equation:
This equation [3] predicts the invariable dependency of the mechanical resistance with the porosity. The slope of the mechanical-porosity-resistance should be the same for all ceramic products and porous structures. This fact is in disagreement with the results of many experiments.

The studies carried out by DATTA et al. (1988) are aimed at highlighting this discrepancy between the theoretical and experimental predictions. These 
estudios recogieron 107 resultados experimentales de la bibliografia de un amplio rango de porosidad y pusieron de manifiesto que el exponente varía con el carácter de la porosidad. El problema es que el exponente $m$ de las ecuaciones [1] y [2] no tiene una clara conexión fisica con la estructura real de la porosidad. Los autores no tuvieron en cuenta la dependencia de $\mathrm{m}$ con las características del poro, tales como la forma y orientación y no indicaron como determinan el valor $m$ a partir de la medida de los parámetros relacionados con la porosidad.

Según el modelo de Boccaccini (1994), los poros en un sistema real se definen como esfenoides con un radio axial efectivo $(\mathrm{z} / \mathrm{x})$ y una orientación en la dirección de la carga aplicada $\left(\alpha_{p}\right)$ siendo los valores medios del sistema considerado. Con estas características la ecuación derivada para expresar la dependencia de la porosidad con el módulo de Young ha sido: studies brought together 107 experimental results of the litterature on a wide range of porosity and pointed up that the exponent varies according to the nature of the porosity. The problem is that the exponent $m$ of the equations [1] and [2] has no clear physical connection with the real structure of the porosity. The authors failed to take into account the dependency of $m$ with the characteristics of the pore, such as the form and orientation and did not mention how the value $m$ was arrived at from the measurement of the parameters related to the porosity.

The pores in a real system are defined as sphenoids with an effective axial ratio $(z / x)$ and an orientation of the direction of the applied force $\left(\alpha_{p}\right)$ which are the mean values for the system under consideration. With this spheroidal characterisation of the pores, the equation derived from the dependency of porosity with Young's model has been proposed:

$$
E=E_{o}\left[1-1,21\left(\frac{z}{x}\right)^{1 / 3} \cdot\left(1+\left(\left[\frac{z}{x}\right]^{-2}-1\right) \cos ^{2} \alpha_{p} P^{2 / 3}\right)\right]
$$

Para el estudio de la resistencia a la fractura de materiales porosos se ha propuesto la siguiente ecuación:
For the study of the resistance to fracture of porous materials, the following equation has been proposed :

$$
\sigma_{f}=\sigma_{o}(1-P)^{k}
$$

donde el exponente $\mathrm{k}$ está relacionado con el factor de concentración de esfuerzos causados en presencia de los poros del material.

Es interesante comparar esta ecuación con la del modelo propuesto por WAGH (1993), que predice una tendencia similar en la variación de la resistencia a la fractura con la porosidad, dada por la ley del poro libre, pero con un significado físico distinto del exponente.

El exponente k en la ecuación [5] está relacionado con el factor de concentración de esfuerzos y depende de su forma y orientación y de la constante de Poisson del material. Puede ser calculado usando la teoría de la elasticidad tridimensional para cavidades esferoidales, BOCCACCINI (1994).

Si no existen orientaciones preferenciales, $\alpha_{p}=54^{\circ}$ puede ser válida para la orientación de poros al azar y la constante de Poisson $v=0,20$ para materiales cerámicos. Además $\mathrm{z} / \mathrm{x}$ puede tomar valores comprendidos entre $z / x=0,3-1$ en función del tipo de poros en el material. Tomando $\mathrm{z} / \mathrm{x}=0,8$, $\alpha_{\mathrm{p}}=54^{\circ}, \mathrm{k}=2,2$; los datos experimentales dan un valor de $m=2,14$. Entonces podemos deducir que where the exponent $k$ is related to the factor of concentration of the force caused by the pores.

It is interesting to compare this equation with the model proposed by WAGH (1993), as it predicts a similar tendency in the variation of the resistance to fracture with the porosity, given by the law of the pore, but with a different physical significance for the exponent.

Exponent $k$ in equation [5] is related to the factor of concentration of the force (stress) of the pores, and depends on the form and the orientation of the pores and on the Poisson ratio of the material. It can be calculated using the theory of three-dimensional elasticity for spheroidal cavities, as per BOCCACCINI (1994).

If there are no preferential orientations, $\alpha_{p}=54^{\circ}$ can be used for the random orientation of the pores, and the Poisson equation $v=0.20$ for ceramic materials. In this way which can take on values of depending on the type of material. If we take, $\alpha_{p}=54^{\circ}, k=2.2$, where as the experimental data gives an adjusted value for $m=2.14$. We can therefore deduce that $k$ is approximately equal to $\mathrm{m}$. It can be stated that the spheroidal model adapts 
$\mathrm{k}$ (obtenido teóricamente) es prácticamente igual a $\mathrm{m}$ (obtenido empíricamente). Por lo tanto, el modelo de Boccaccini se adapta mejor a los datos experimentales que el modelo de Wagh.

El modelo de WAGH et al. (1993) tiene limitaciones en su aplicabilidad para el ajuste de datos experimentales y no tiene un carácter predictivo. Dado que los distintos modelos matemáticos expuestos se hallan en continua evolución, debido a que no se ha hallado todavía un modelo universal válido que ajuste los datos teóricos a los datos experimentales obtenidos para probetas cerámicas, se ha optado por abordar el estudio de ambos parámetros de un modo independiente. Por este motivo, en este trabajo, sólo se han obtenido relaciones a nivel cualitativo entre ambos parámetros relacionándolos con las fases minerales presentes y la formación de fase vítrea.

Con todo lo expuesto se ha puesto de manifiesto la dificultad que entraña establecer una relación teórica entre resistencia mecánica y porosidad. Por ello, se ha enfocado esta investigación en el análisis de la resistencia mecánica a la flexión de probetas cerámicas cocidas a distintas temperaturas y posterior estudio de su textura porosa. A partir de los datos obtenidos se intenta establecer relaciones entre ambos parámetros.

Por otra parte, se va a considerar el estudio de la textura del cuerpo cerámico principalmente en relación con la porosidad existente, así como de su distribución, ya que debe condicionar sus características y especificaciones.

La porosidad es una de las variables más importantes implicadas en la caracterización de una pieza cerámica. Las reacciones que implican fases gaseosas suelen darse frecuentemente en el proceso de cocción de las arcilla, por lo que puede comprobarse que la cinética de muchas reacciones de oxidación y descomposición está influída considerablemente por la permeabilidad de los sólidos porosos hacia los gases. En el proceso de calentamiento de una plaqueta cerámica, los gases presentes en el interior de los poros, inicialmente se dilatan, produciéndose un flujo gaseoso desde el interior de la plaqueta hacia la atmósfera del horno. Este flujo gaseoso depende, básicamente, de la permeabilidad del sólido (AMORÓS y col., 1992).

Por otro lado, varios autores han mostrado que la porosidad de piezas cerámicas es un importante factor en su resistencia a la congelación. También, la porosidad de un material cerámico está íntimamente relacionada con su resistencia mecánica, como se ha mencionado anteriormente. itself much better to the experimental data than the Wagh model.

In short, the model proposed by WAGH et al. (1993) is limited in its applicability for the adjustment of experimental data and has no predictive character. Given the fact that the different mathematical models presented are in state of constant evolution, because no valid model that can adjust theoretical data to experimental data obtained by means of ceramic bodies has yet to be found, the study of these two parameters has been carried out independently. For this reason, only relationships on a qualitative level between both of the parameters relating them with the mineral phases present and the formation of the vitreous phase have been obtained.

With all of this taken into account, the difficulty involved in establishing a theoretical relationship between mechanical resistance and porosity is evident. The focus of this study, therefore, has been in the analysis of the mechanical resistance to the flexion of ceramic tile bodies fired at different temperatures and the subsequent study of their porous texture. We have attempted to establish relationships between both parameters from the data obtained.

It is no secret that the mechanical properties of ceramic pieces is very important in determining their utilisation and application for any specific function.

Porosity is one of the most important variables involved in the characterisation of a ceramic piece. Reactions involving gaseous phases are frequent in the firing process of the clays, and it can be shown that the cinetics of many of reactions of oxidation and decomposition is influenced considerably by the permeability of the porous solid to the gases. In the process of heating the ceramic tile body, the gases present in the interior of the initially open pores dilate, and this produces a gaseous flow from the interior of the tile body to the recesses of the atmosphere of the kiln. This gaseous flow basically depends on the permeability of the solid (AMORÓS et al., 1992).

On the other hand, several authors have shown that the porosity of ceramic pieces is an important factor in their resistance to freezing temperatures. Also, the porosity of a ceramic body is intimately related to its mechanical resistance, as we mentioned above. 
Por todas estas razones, estamos convencidos de la importancia de la caracterización de la textura porosa de las pastas de plaquetas cerámicas obtenidas por extrusión y cocidas a diferentes temperaturas y diferentes composiciones. Esta caracterización se ha llevado a cabo por medidas de intrusión de mercurio.

\section{METODOLOGÍA}

Para la realización de este trabajo se han fabricado con arcillas procedentes de cinco yacimientos de la provincia de Castellón unas probetas cilíndricas de $10 \mathrm{~cm}$ de largo y $10 \mathrm{~mm}$ de diámetro obtenidas mediante extrusión y lo suficientemente uniformes y exactas para realizar con ellas los ensayos mecánicos adecuados.

Las probetas, moldeadas por extrusión, se han secado para eliminar la humedad en estufa a $60^{\circ} \mathrm{C}$ durante 24 horas hasta peso constante $\mathrm{y}$, posteriormente, cocidas en horno de mufla eléctrico con un período de residencia de 35 minutos para todas ellas en la que se mantiene la máxima temperatura en cada uno de los distintos procesos de cocción: $900^{\circ} \mathrm{C}, 950^{\circ} \mathrm{C}$, $1.000^{\circ} \mathrm{C}, 1.050^{\circ} \mathrm{C}, 1.100^{\circ} \mathrm{C}$ y $1.150^{\circ} \mathrm{C}$. Se escogieron estas temperaturas máximas por su proximidad con las que se alcanzan en diversos procesos de cocción en la industria cerámica, tal como se explica en SANFELIU (1991).

La caracterización química, mineralógica y granulométrica de los afloramientos de arcillas más representativos se ha estudiado previamente por JORDÁN y col. (1993-94) (Tablas 1, 2 y 3).
For all these reasons, we are convinced of the importance of releasing a characterisation of the porous texture of the tile bodies obtained by extrusion and fired at different temperatures for different compositions. This characterisation has been carried out through mercury injection porosity measurement .

\section{METHODOLOGY}

For this project, cylindrical tile bodies $10 \mathrm{~cm}$ long and $10 \mathrm{~mm}$ in diameter were produced using clays from five deposits in the province of Castellon (Spain). The tile bodies were obtained by means of extrusion and were sufficiently uniform and exact to be able to carry out the appropriate mechanical tests with them.

The extruded pieces, were dried to eliminate humidity in a drying kiln at $60{ }^{\circ} \mathrm{C}$ for a period of 24 hours until their weight was constant, and then fired in an electric muffle furnace with a residence period of 35 minutes for all of the pieces, during which a maximum temperature was reached and maintained during each of the different firing processes: $900{ }^{\circ} \mathrm{C}, 950^{\circ} \mathrm{C}, 1.000^{\circ} \mathrm{C}, 1.050^{\circ} \mathrm{C}$, $1.100^{\circ} \mathrm{C}$ and $1.150^{\circ} \mathrm{C}$. These maximum temperatures were selected because they are similar to those that are reached in the various firing processes in the ceramics industry, as explained in SANFELIU (1991).

The mineralogical, chemical and granulometric characterisation of the clays was carried out previously, JORDÁN et al. (1993-94) (Tables 1, 2 and 3).

TABLA 1 (TABLE 1)

Análisis mineralógico semicuantitativo. Método de Chung (1974)

(Semi-cuantitative mineralogical analysis, Chung method (1974))

\begin{tabular}{|c|c|c|c|c|c|c|c|c|}
\hline $\begin{array}{c}\text { Muestra } \\
\text { (Sample) }\end{array}$ & $\mathbf{Q}$ & $\mathbf{C c}$ & $\mathbf{D o}$ & $\mathbf{M}+\mathbf{I}$ & $\mathbf{C}+\mathbf{K}$ & $\mathbf{H m}$ & $\mathbf{F d}_{\mathrm{K}}$ & PIg \\
\hline LA & 39 & 4 & $<1$ & 40 & 8 & 2 & $<1$ & 5 \\
\hline ZC & 35 & 3 & - & 48 & 10 & 2 & - & 2 \\
\hline CE & 15 & $<1$ & - & 49 & 31 & - & 4 & - \\
\hline JT & 27 & 6 & $<1$ & 31 & 30 & 3 & $<1$ & $<1$ \\
\hline FM & 31 & 2 & - & 31 & 20 & 6 & 10 & - \\
\hline
\end{tabular}

Leyenda: Q (cuarzo), Cc (calcita), Do (dolomita, M + I (moscovita + illita), C+K (clorita + caolinita), Hm (hematita), Fdk (feldespatos potásicos) y Plg (plagioclasa)

(Legend: $Q$ (quartz), Cc (calcite), Do (dolomite), $M+I$ (muscovite+ illite), C+K (chlorite + kaolinite), Hm (hematite), Fdk (K-feldspars) y Plg (plagioclases)). 
TABLA 2 (TABLE 2)

Análisis químico de los elementos principales

(Chemical analysis of principal elements)

\begin{tabular}{|c|c|c|c|c|c|c|c|c|c|c|}
\hline$\%$ & $\mathrm{SiO}_{2}$ & $\mathbf{A l}_{\mathbf{2}} \mathbf{O}_{3}$ & $\mathrm{Fe}_{2} \mathrm{O}_{3}$ & $\mathbf{K}_{2} \mathbf{O}$ & $\mathrm{CaO}$ & MgO & $\mathrm{TiO}_{2}$ & MnO & $\mathbf{P}_{2} \mathbf{O}_{3}$ & P.F. \\
\hline LA & 65,96 & 14,68 & 4,37 & 4,24 & 2,18 & 1,28 & 0,76 & 0,04 & 0,11 & 6,30 \\
\hline $\mathrm{CE}$ & 55,05 & 17,34 & 5,52 & 3,87 & 4,03 & 1,64 & 0,71 & 0,05 & 0,19 & 10,70 \\
\hline $\mathrm{ZC}$ & 61,25 & 18,09 & 4,86 & 4,84 & 1,64 & 1,18 & 0,83 & 0,02 & 0,11 & 6,40 \\
\hline FM & 59,72 & 18,37 & 668 & 3,44 & 1,35 & 1,65 & 0,86 & 0,07 & 0,12 & 7,00 \\
\hline $\mathrm{JT}$ & 56,00 & 17,20 & 9,00 & 2,95 & 5,05 & 1,32 & 0,66 & 0,08 & 0,12 & 6,88 \\
\hline
\end{tabular}

TABLA 3 (TABLE 3)

Resultados del análisis granulométrico. Estimación del diámetro medio de partícula y promedio de la superficie específica

(Results of the granulometric analysis. Estimation of the average particle diameter and average specific surface)

\begin{tabular}{|c|c|c|c|c|}
\hline $\begin{array}{c}\text { Muestra } \\
\text { (Sample) }\end{array}$ & $\begin{array}{c}\% \text { arcilla } \\
(\% \text { clay) } \\
(<2 \mu \mathrm{m})\end{array}$ & $\begin{array}{c}\% \text { (arcilla+ } \\
\text { (limo) } \\
(\% \text { (lime+ } \\
\text { clay)) } \\
(2-20 \mu \mathrm{m})\end{array}$ & $\begin{array}{c}\text { Diámetro } \\
\text { Promedio } \\
\text { (Average diameter } \\
(\boldsymbol{\mu}))\end{array}$ & $\begin{array}{c}\text { Superficie } \\
\text { Específica } \\
\text { (Specific } \\
\text { surface) } \\
\left(\mathbf{m}^{2} / \mathbf{g}\right)\end{array}$ \\
\hline ZC & 25 & 52 & 7,80 & 0,7995 \\
\hline JT & 49 & 86 & 5,00 & 0,9731 \\
\hline FM & 26 & 72 & 5,00 & 0,9542 \\
\hline CE & 38 & 84 & 5,10 & 0,9441 \\
\hline LA & 28 & 70 & 6,74 & 0,7756 \\
\hline
\end{tabular}

Se ha realizado una determinación analítica de la fracción arcilla, limo y arena, así como la distribución del tamaño de partícula en cada una de las muestras.

Una vez cocidas a las temperaturas indicadas se han llevado a cabo los correspondientes ensayos en un banco universal de ensayos mecánicos INSTROM con el fin de determinar para cada una de ellas (10 probetas por composición) su resistencia a la fractura por flexión.

Para los ensayos de resistencia a la flexión se ha usado una máquina INSTROM 1341 con sistema de control digital aplicando la tensión en cuatro puntos separados dos a dos por $0,04 \mathrm{~m}\left(\mathrm{l}_{1}\right)$ y $0,02 \mathrm{~m}\left(\mathrm{l}_{2}\right)$ respectivamente, con el fin de obtener un valor estadístico medio representativo (Figura 1).
An analytical determination of the different samples used was also carried out in order to define the presence in the samples of sizes of particle, fine or course sand, lime and clay and their granulometric distribution in each of the samples.

Once the bodies had been fired at the indicated temperatures, the corresponding tests were carried out on them in an INSTROM universal bank of mechanical tests in order to determine for each of them their resistance to fracture by flexion.

The tests for resistance to flexion were done in an INSTROM 1341 with digital control system, applying tension at four points separated two by two by $0.04 \mathrm{~m}\left(l_{2}\right)$ and $0.02 \mathrm{~m}\left(l_{1}\right)$ respectively, in order to obtain a representative average statistical value (Figure 1). 


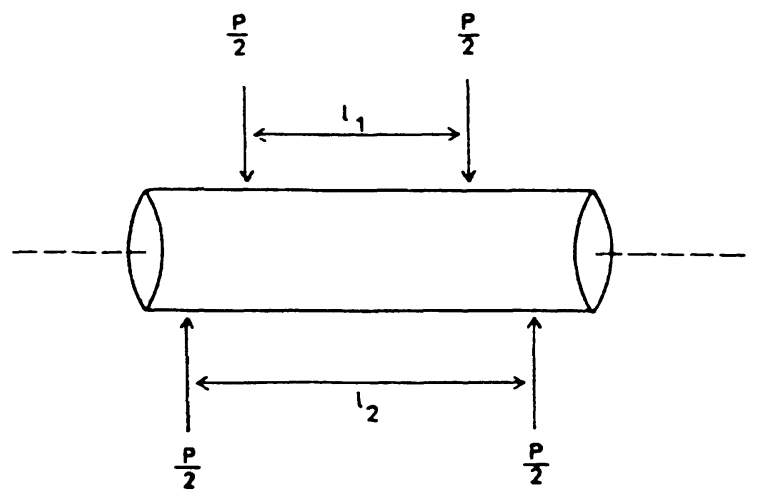

Figura 1.- Esquema de una probeta cilíndrica señalando las fuerzas aplicadas sobre cuatro puntos y las distancias entre ellos.

Figure 1.- Diagram of a cylindrical piece, indicating the forces applied at the four points and the distances between them.

La velocidad del pistón se ajustó a $\mathrm{v}=0,022 \mathrm{~mm} / \mathrm{s}$, el límite mínimo de carga fue de $1.000 \mathrm{kN}$ y el límite mínimo de posición $0,0 \mathrm{~mm}$. El límite de protección fue de $20,0 \mathrm{~mm}$.

A partir de los datos obtenidos en el ensayo de resistencia mecánica a la flexión, se ha calculado el módulo de resistencia mecánica a la flexión $(\sigma)$, según la expresión:
The velocity of the piston was set at $v=0.022 \mathrm{~mm} / \mathrm{s}$, the minimum charge limit was $1.000 \mathrm{kN}$ and the minimum position limit was set at 0,0 $\mathrm{mm}$. The limit of protection was $20.0 \mathrm{~mm}$.

From the data obtained in the mechanical resistance to flexion, the module of mechanical resistance to flexion $(\sigma)$ was calculated, according to the expression:

$$
\sigma=\frac{P\left(l_{2}-l_{1}\right)}{\pi r^{3}}[6]
$$

La distribución del tamaño de los poros de cada una de las probetas cocidas se ha determinado por porosimetría de mercurio. La porosimetría de mercurio se basa en la introducción de mercurio, líquido no mojante, que tiene una tensión superficial $\mathrm{T}$ $\mathrm{y}$ un ángulo de contacto $\mathrm{C}$, en el interior de poros de radio $\mathrm{R}$ (LORICI y BRUSA, 1991). El cálculo de la presión aplicada se efectúa mediante la ecuación de WASHBURN, que relaciona la presión aplicada y el radio de los capilares:
The distribution of the size of the pores of each of the fired tile bodies was determined by mercury porosymetry. Mercury porosymetry is based on the introduction of mercury, a non-wetting liquid, which has a superficial tension $T$ and an angle of contact $C$, in the interior of pores with radius $R$ (LORICI $y$ BRUSA, 1991). The calculation of the applied pressure is carried out using WASHBURN's equation, which relates the applied pressure and the radius of the capillaries:

$$
P=\frac{-2 T \cos C}{R}[7]
$$

La presión aplicada es inversamente proporcional al tamaño de poro. La ecuación supone que todos los poros son cilíndricos, no tortuosos y tienen igual longitud y tamaño, lo que si bien no es cierto, no impide obtener resultados en términos de diámetros cilíndricos equivalentes. A partir de las curvas de intrusión obtenidas se ha determinado la distribución del tamaño de poro, el radio medio geométrico y la densidad aparente en cada una de las probetas así como la superficie total de los poros (ELLINGSON, 1987).

Se ha utilizado un penetrómetro de mercurio PORESIZER $9320 \mathrm{~V} 1.01$, con constante $10,79 \mu \mathrm{L} / \mathrm{pF}$ y ángulo de contacto de $130^{\circ}$. El sistema de medida
The equation supposes that all of the pores are cylindrical, non-circuitous and that they are of the same length and size. If this is not true, it does not impede the obtaining of results in terms of equivalent cylindrical diameters. From the intrusion curves obtained, the distribution of pore size, average geometric radius and the apparent density was determined for each of the tile bodies, as well as the total surface of the pores (ELLINGSON, 1987).

A PORESIZER 9320 V1.01 mercury penetrometer was used, with $10,79 \mu \mathrm{L} / \mathrm{pF}$ constant and $130^{\circ}$ angle of contact. The measuring system used 
utilizado mide la variación del volumen de mercurio que penetra en los poros de las probetas cerámicas cocidas al aumentar la presión. Un incremento de la presión supone que el mercurio sea capaz de ocupar poros de menor tamaño (LUCARELLI y VENTURI, 1995).

El aparato es capaz de someter el sistema a la presión adecuada, al tiempo que da información sobre la presión aplicada y el volumen de mercurio introducido en los poros. Estos equipos están constituidos por una bomba de vacio, unidades de medida de presión y del nivel de mercurio y cápsulas para colocación de las muestras. La salida de datos está conectada a un PC que los registra y representa gráficamente.

Las curvas utilizadas para determinar la distribución del tamaño de poro representan en ordenadas el logaritmo del volumen acumulativo de intrusión en función del diámetro en $\mu \mathrm{m}$ (Figura 2). El volumen acumulativo de intrusión viene dado en $\mathrm{ml} / \mathrm{g}$. measures the variation in the volume of mercury that penetrates into the pores of the fired ceramic tile bodies when the pressure is increased. An increase in the pressure indicates that the mercury is able to occupy the smaller size pores (LUCARELLI y VENTURI, 1995).

This apparatus is capable of submitting the system to the adequate pressure, and at the same time provides information on the pressure applied and the volume of mercury introduced into the pores. This piece of equipment consists of a vacuum pump, units of measure for pressure and for the level of mercury, and capsules to place the samples in. The data output is connected to a PC which records the data and provides a graphic representation of it.

The curves used to determine pore size distribution show the logarhythm of the accumulated volume of intrusion against the diameter in $\mu m$ (Figure 2). The accumulated volume of intrusion is given in $\mathrm{ml} / \mathrm{g}$.

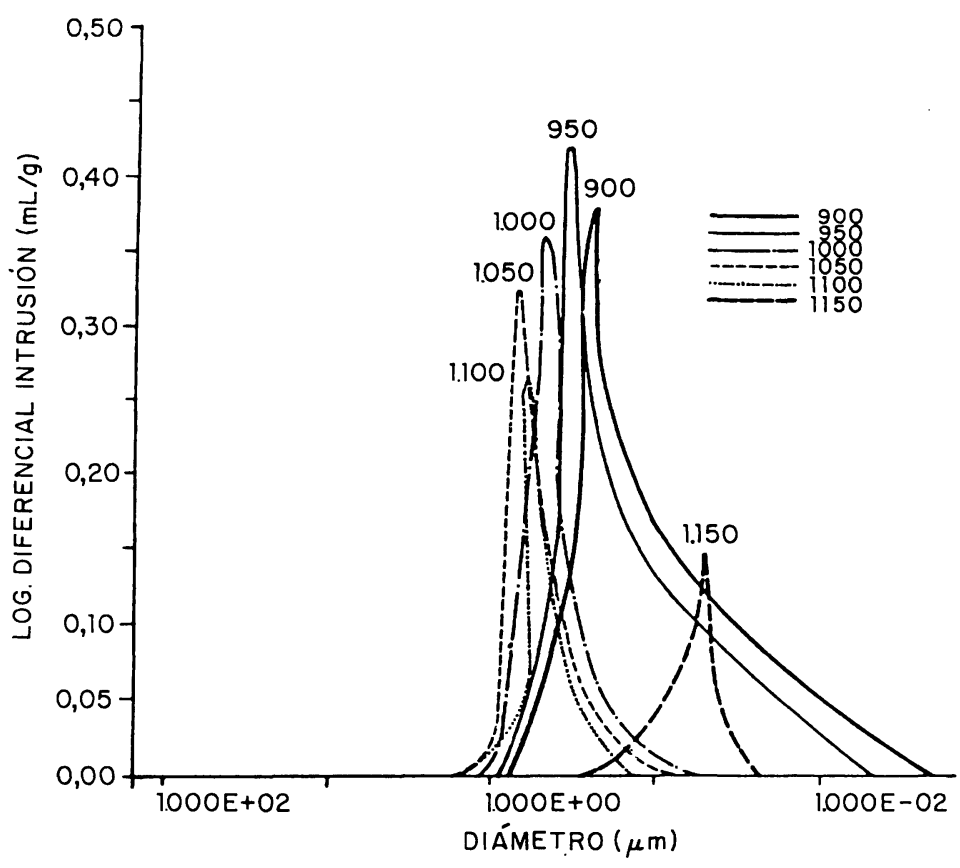

Figura 2.- Logaritmo diferencial intrusión $(\mathrm{ml} / \mathrm{g})$ vs diámetro.

Figure 2.- Differential intrusion logarithm ( $\mathrm{ml} / \mathrm{g})$ against pore diameter.

A partir de las curvas de intrusión se ha calculado para cada una de las probetas cocidas el volumen total de intrusión $\left(\mathrm{V}_{\mathrm{T}}\right)$, el área total de poro $\left(\mathrm{S}_{\mathrm{T}}\right)$, el radio medio de poro (r) así como la densidad aparente de las muestras ( $\varphi$ ap). Se ha determinado el volumen del área superficial de los poros suponiendo que son cilindros. Para ello se ha utilizado la ecuación:
The total volume of intrusion $\left(V_{T}\right)$, the total pore area $\left(S_{\tau}\right)$, the average pore radius $(r)$, as well as the apparent density of the samples ( $\varphi$ ap) was calculated for each of the fired tile bodies from the intrusion curves. The value of the superficial area of the pores was determined supposing they were cylindrical. The following equation was used:

$$
S_{T}=\sum_{P_{0}}^{P_{\max }} \frac{4 \Delta V_{i}}{d_{i}}[8]
$$


en la que la presión mínima y máxima que se alcanza con el porosímetro de mercurio utilizado es $\mathrm{Po}$ y $\mathrm{Pi}$ respectivamente, $\Delta \mathrm{Vi}$ es el volumen de mercurio intruido entre dos medidas consecutivas a las presiones $\mathrm{Pi}$ y $\mathrm{P}_{\mathrm{i}+1}$ y di es el diámetro medio entre las presiones Pi y $P_{i+1}$.

La porosidad abierta de las muestras cocidas $(\varepsilon)$ se ha calculado a partir de la expresión:

$$
\varepsilon=V_{T} \cdot \varphi_{\text {up }} \text { [9] }
$$

donde $\mathrm{V}_{\mathrm{T}}$ es el volumen total de intrusión de mercurio por unidad de masa y $\varphi_{\text {ap }}$ es la densidad aparente de la pieza cocida.

Por otra parte, se han utilizado las leyes de Darcy y Poiseuille para obtener la ecuación que nos ha permitido calcular el coeficiente de permeabilidad. El coeficiente se ha calculado suponiendo la hipótesis de que las probetas cocidas están formadas por un sistema de poros cilíndricos no tortuosos de igual longitud y radio, lo cual es una simplificación e idealización del sistema poroso. Para el cálculo del coeficiente de permeabilidad se utilizó la ecuación:

$$
K p=\frac{r^{2} \cdot \varepsilon}{8}[10]
$$

siendo:

$\mathrm{r}=$ radio medio capilar $(\mathrm{m})$

$\varepsilon=$ porosidad.

$\mathrm{Kp}=$ coeficiente de permeabilidad $\left(\mathrm{m}^{2}\right)$

\section{RESULTADOS Y DISCUSIÓN}

Con los datos obtenidos en los ensayos mecánicos, utilizando las distintas probetas cocidas a diferentes temperaturas, se han construido las gráficas en las que se representa la variación del módulo de rotura con la temperatura de cocción. Estas pruebas nos ofrecen unos datos valiosos sobre el comportamiento mecánico de las probetas.

En general (Figura 3), se observa un aumento del módulo de resistencia a la flexión en todas las series asociado al incremento de la temperatura de cocción y a la reducción de la porosidad. Este aumento se hace más acusado a partir de los $1.000^{\circ} \mathrm{C}$, con una pendiente muy pronunciada de la recta que une el punto correspondiente a $1.050^{\circ} \mathrm{C}$ con el de $1.100^{\circ} \mathrm{C}$. A partir de esta temperatura de cocción el módulo de resistencia a la flexión se mantiene prácticamente constante para las series JT, CE y FM.

La resistencia mecánica a la flexión depende del contenido en fases cristalinas y está directamente relacionada con el porcentaje de carbonato cálcico que aporta $\mathrm{CaO}$ formador de silicoaluminatos cálcicos in which the maximum and minimum pressure reached with the mercury porosimeter is $P o$ and $P i$ respectively, $\Delta V i$ is the volume of mercury introduced between two consecutive measurements of the pressures $P i$ and $P_{i+1}$ and $d_{i}$ is the average diameter between pressures $P i$ and $P_{i+1}$.

The open porosity of the fired samples $(\varepsilon)$ is calculated from the expression:

\begin{abstract}
where $V_{T}$ is the total volume of mercury intrusion per unit of mass and $\varphi_{a p}$ is the apparent density of the fired piece.
\end{abstract}

On the other hand, the laws of Darcy and Poiseuille have been used to obtain the equation which allows for the calculation of the coefficient of permeability. This coefficient is calculated assuming the hypothesis that the fired tile bodies are formed by a system of non-circuitous cylindrical pores of the same length and radius, which is in effect a simplification and idealisation of the porous system. For the calculation of the coefficient of permeability, the following equation was used:

$$
\begin{aligned}
& \text { being: } \\
& r=\text { capillary mean radius }(m) \\
& \varepsilon=\text { porosity. } \\
& K p=\text { coefficient of permeability }\left(m^{2}\right)
\end{aligned}
$$

\section{RESULTS AND DISCUSSION}

With the data obtained in the INSTROM, using the different tile bodies which were fired at different temperatures, graphs were constructed to represent the variation of the rupture module with the temperature. These tests provide us with valuable data on the mechanical behaviour of the tile bodies.

Generally speaking (Figure 3), an increase in the resistance to flexion module was noted in all of the series, and this was related to the increase in the maturing temperature and to the reduction of porosity. This increase was more pronounced from $1.000^{\circ} \mathrm{C}$, with a very pronounced slope of the straight line that joins the point corresponding to $1.050{ }^{\circ} \mathrm{C}$ with the point at $1.100{ }^{\circ} \mathrm{C}$. From the point of this maturing temperature the resistance to flexion module remains practically constant for the series JT, CE and FM.

Mechanical resistance to flexion depends on the crystalline phase content and is directly related to the percentage of calcium carbonate in that it is a supplier of $\mathrm{CaO}$ and a former of calcium silico-aluminates between 


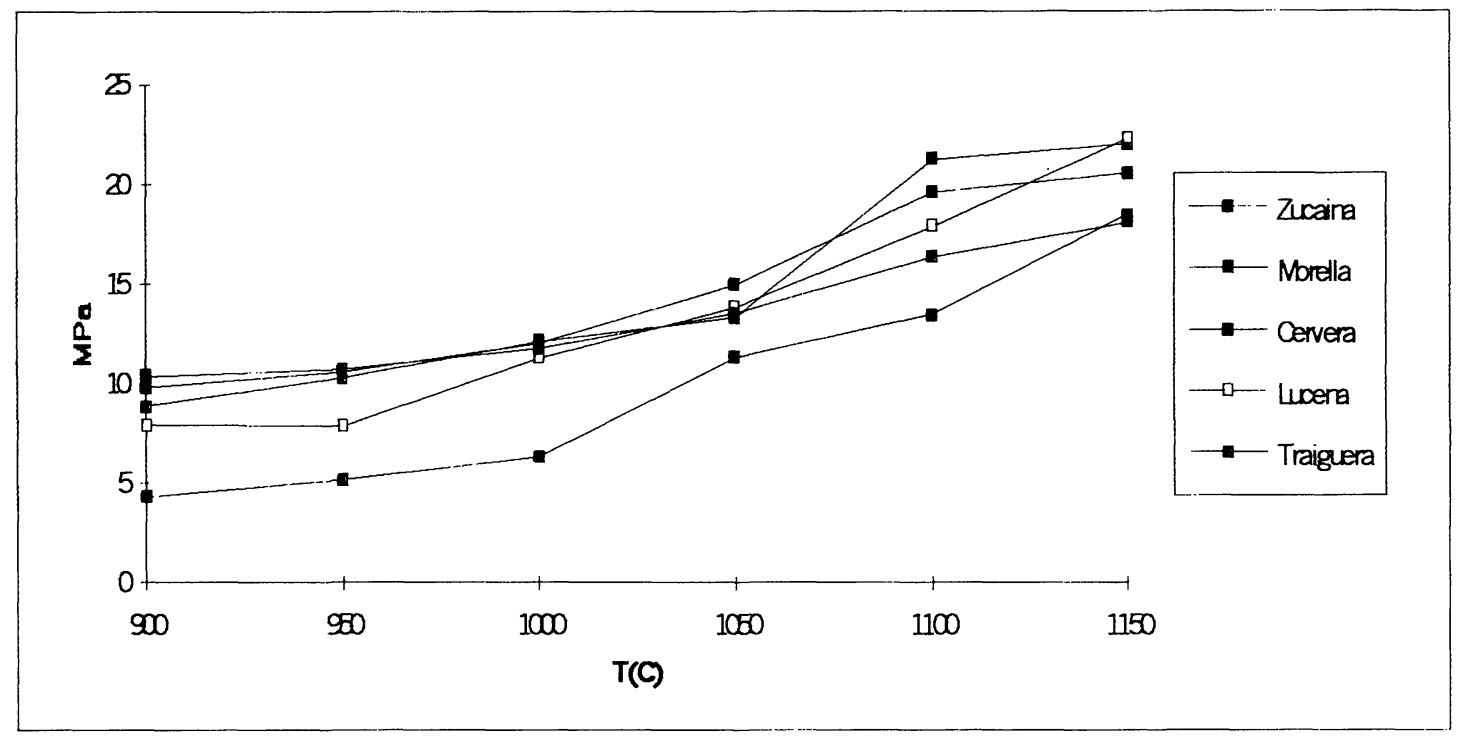

Figura 3.- Representación de la variación del módulo de resistencia a la flexión calculado para cada temperatura y composición.

Figure 3.- Illustration of the variation of the resistance module to flexion for each composition as a function of firing temperature.

entre $950-1.050^{\circ} \mathrm{C}$. La presencia de fases cristalinas en la matriz cerámica confiere a la pieza una resistencia mecánica elevada de las piezas cocidas.

El mayor módulo de resistencia a la flexión para las probetas cocidas a $950{ }^{\circ} \mathrm{C}$ se da en las series JT $(10,72 \mathrm{MPa}), \mathrm{CE}(10,59 \mathrm{MPa})$ y FM $(10,29 \mathrm{MPa})$ estando las series LA $(7,88 \mathrm{MPa})$ y ZC $(5,18 \mathrm{MPa})$ muy por debajo de estos valores.

Otro aspecto deducible de los ensayos de resistencia mecánica es la contribución del contenido en fracción arcilla de las series estudiadas al aumento del módulo de resistencia a la flexión. Este hecho puede explicarse por la descomposición total de las mineralizaciones arcillosas (illitas, caolinitas, cloritas, etc.), que tiene lugar hacia los $1.000^{\circ} \mathrm{C}$, cuando todavía no han reaccionado los diferentes minerales. Las diferencias observadas pueden ser debidas a las variaciones en la concentración de los distintos minerales de la arcilla, lo que puede explicarse por las reacciones de superficie entre ellos que pueden tener lugar a una u otra temperatura.

Desde el punto de vista de la resistencia mecánica de las probetas elaboradas con las composiciones objeto de estudio, la temperatura óptima de cocción la hemos situado en el intervalo comprendido entre 1.050 y $1.100^{\circ} \mathrm{C}$ donde se alcanza una buena resistencia mecánica para las series consideradas. Sólo las muestras de las series ZC y LA mejoran su comportamiento mecánico de forma apreciable cuando se alcanzan los $1.150^{\circ} \mathrm{C}$.
950-1.050 ${ }^{\circ} \mathrm{C}$. The presence of crystalline phases in the ceramic matrix provides the piece with a high fired mechanical resistance.

The greatest resistance to flexion module for the bodies fired at $950{ }^{\circ} \mathrm{C}$ was seen in the series $J T$ (10.72 MPa), CE (10.59 MPa) and FM (10.29 MPa), with the series $L A(7.88 \mathrm{MPa})$ and $Z C(5.18 \mathrm{MPa})$ much below these values.

Another deducible aspect of the mechanical resistance tests is the contribution of the fraction of clay in the series studied to the increase in the resistance to flexion module. This fact can be accounted for the total decomposition of the clayish mineralisations (illites, kaolinites, chlorites, etc.), which takes place at about $1.000{ }^{\circ} \mathrm{C}$, when the different minerals have still not reacted. The differences observed could be due to variations in the concentration of the different minerals in the clay, which could be explained by the surface reactions between them which can occur at one temperature or another.

From the point of view of the mechanical resistance of the bodies made up with the compositions that are the objective of this study, we have established the optimum firing temperature to be in the interval between 1.050 and $1.100{ }^{\circ} \mathrm{C}$, where a good mechanical resistance for the series under consideration is reached. Only samples of the series $Z C$ and $L A$ show an appreciable improvement in their mechanical behaviour when they reached $1.150{ }^{\circ} \mathrm{C}$. 
En el intervalo de temperaturas de cocción ensayado, la porosidad de las probetas cocidas va disminuyendo conforme aumenta la temperatura de cocción. Los valores del coeficiente de permeabilidad $\mathrm{Kp}$ y del radio medio de poro (r) de las piezas cocidas aumentan considerablemente con la temperatura hasta alcanzar un máximo para luego descender progresivamente al continuar el incremento térmico. Como puede observarse el salto en la resistencia a la flexión $(\sigma)$ se corresponde con la disminución de la porosidad $(\varepsilon)$. Esta distribución de la porosidad, tras la extrusión, no es homogénea por lo que la resistencia mecánica de las probetas se ha determinado precisamente en la zona media. Se ha comprobado que la resistencia mecánica de las probetas cocidas normalmente es suficiente si su porosidad es la correcta (Figura 4).
In the interval of firing temperatures tested, the porosity of the fired bodies diminishes as the firing temperature increases. The values for the coefficient of permeability $(\mathrm{Kp})$ and the average pore radius $(r)$ of the fired pieces increases considerably with the temperature until it reaches a maximum, to later progressively descend as the thermal increment continues. As can be noted, the jump in the resistance to flexion $(\sigma)$ corresponds to the decrease in porosity (ع). This distribution of the porosity, after the extrusion, is not homogeneous because the mechanical resistance of the ceramic bodies has been determined precisely in the mid zone. It has been shown that the mechanical resistance of the tile bodies is sufficient if the porosity is correct (Figure 4).

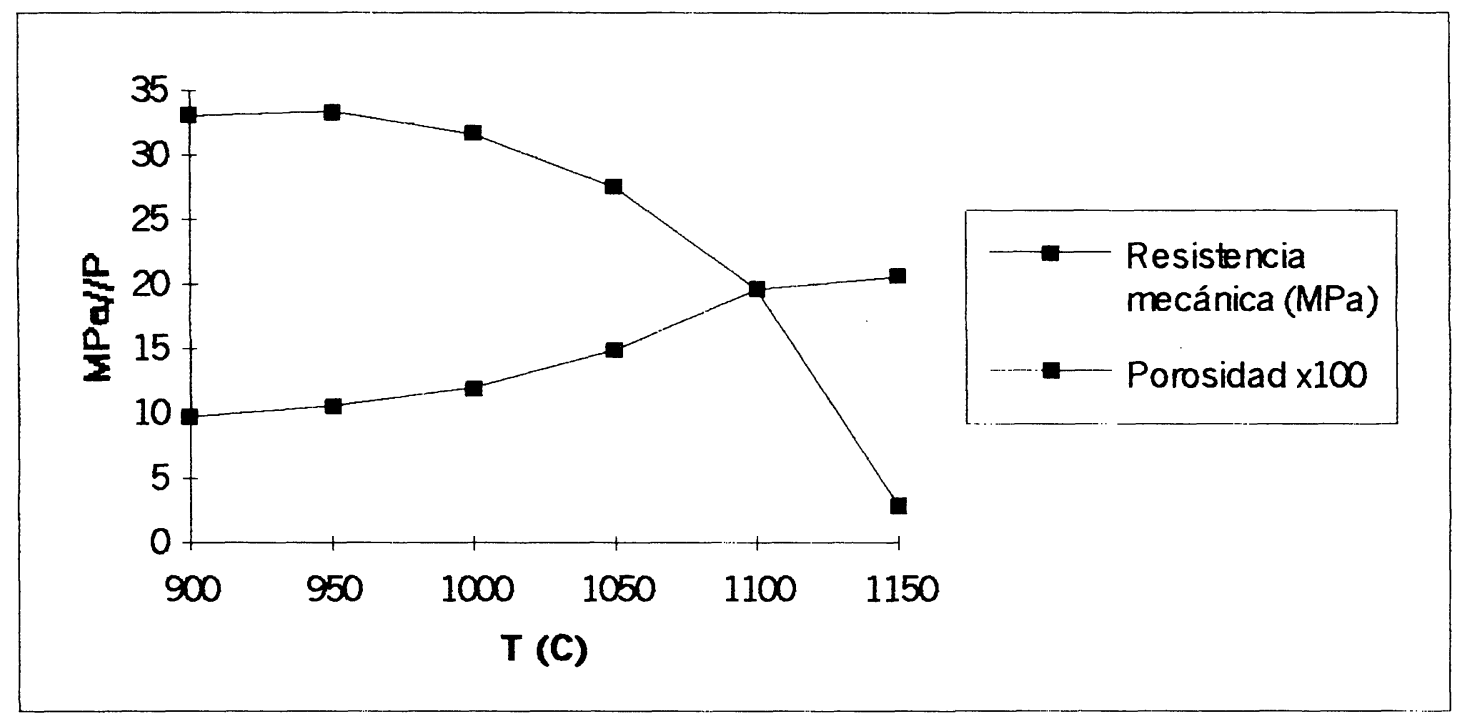

Figura 4.- Evolución del módulo de resistencia mecánica a la flexión $(\sigma)$ frente a la porosidad $(\varepsilon)$ en probetas cocidas de la serie CE.

Figure 4.- Evolution of mechanical resistance to flexion module $(\sigma)$ and porosity module $(\varepsilon)$ against temperature in series $C E$ fired ceramic bodies.

A $950^{\circ} \mathrm{C}$ las arcillas bajas en carbonatos dan un bizcocho constituido por fases prácticamente amorfas con una estructura "espumosa" a base de cristales de cuarzo y poros.

Entre los 900 y los $1.000^{\circ} \mathrm{C}$ tiene lugar el proceso de sinterización, que consiste en una compactación por agregación de partículas. Este proceso no es completo, de manera que las probetas cerámicas son todavía bastante porosas. Hacia los $1.000^{\circ} \mathrm{C}$, tal como se observa en los gráficos $r=f(T)$, se produce un aumento de los poros mayores (entre 1 y $10 \mu \mathrm{m}$ ). Este fenómeno coincide con la destrucción de la red cristalina de las illitas y cloritas y su recristalización en cuarzo y espinela (tipo hercinita) principalmente.

Entre 1.050 y $1.100^{\circ} \mathrm{C}$ se produce una importante disminución de la porosidad coincidiendo con el inicio
At $950{ }^{\circ} \mathrm{C}$ clays that are low in carbonates produce a biscuit made up of phases which are practically amorphous, with a "frothy" structure of quartz crystals and pores.

Between 900 and $1.000^{\circ} \mathrm{C}$ a sintering process takes place, which consists in the aggregation compacting of particles. This process is not complete, so the ceramic tile bodies are still quite porous. Towards $1.000^{\circ} \mathrm{C}$, as can be seen in the graphs $r=f(T)$, the larger pores are seen to increase (between 1 and $10 \mu \mathrm{m}$ ). This phenomenon coincides with the destruction of the crystalline network of illites and chlorites and their re-crystallisation into quartz and spinel (hercynite type) principally.

Between 1.050 and $1.100^{\circ} \mathrm{C}$ a considerable decrease in the porosity occurs, coinciding with the beginning 
de la vitrificación. Se inicia por tanto una importante disminución del radio medio de poro. A $1.150^{\circ} \mathrm{C}$ las probetas gresifican y se cierran los poros disminuyendo notablemente la porosidad.

Para las composiciones estudiadas las variaciones del diámetro medio de poro con la temperatura se deben principalmente a dos factores que se producen de forma simultánea, pero con efectos contrarios. Por un lado, se produce una disminución del tamaño de poro a medida que va disminuyendo la porosidad debido a un incremento del contenido en fase líquida y a una disminución de la viscosidad. Por el contrario, como consecuencia de la heterogeneidad microestructural de las probetas en crudo, con el aumento de la temperatura de cocción asistimos a una eliminación progresiva de los poros de menor tamaño, lo cual conduce a contracciones diferenciales entre las distintas microrregiones de la probeta y como consecuencia se produce un aumento del diámetro medio de poro (Tabla 4: a, b, c, d y e). A medida que aumenta el contenido en fase líquida y disminuye su viscosidad, además de producirse la reducción de la porosidad de las probetas, se bloquea parcialmente el sistema capilar preexistente (AMORÓS y col., 1992), lo que reduce todavía más la porosidad interconectada. Como resultado de estos dos efectos antagónicos se observan curvas (diámetro medio de poro vs temperatura) con la presencia de un máximo (Figuras 5 y 6). La reducción de la porosidad lleva asociada el aumento de la resistencia mecánica de la matriz arcillosa al mismo tiempo que aumenta la expansión térmica de la pieza cerámica.

El aumento que experimenta el radio medio de poro de la pieza cerámica con la reducción de la porosidad es tanto más acusada cuanto menos uniforme es la microestructura de la pieza en crudo. A partir de $1.000^{\circ} \mathrm{C}$ en algunas piezas o de $1.050^{\circ} \mathrm{C}$ en otras, se alcanzan of vitrification. A considerable decrease in the average radius of the pores therefore also begins. At $1.150{ }^{\circ} \mathrm{C}$ the tile bodies become earthenware and the pores close, and the porosity decreases significantly.

For the compositions studied, the variations in the average pore size diameter is mainly due to two factors that are produced simultaneously but with opposite effects. These effects are developed in the pieces in relation to the degree in which their porosity diminishes due to an increase in the content in liquid phase and to a diminishing of their viscosity. On the other hand, as a consequence of the microstructural heterogeneity of the raw tile bodies, with the increase in the firing temperature we find a progressive elimination of the presence of the smaller pores, which bring about differential contractions among the different micro-regions of the tile body and as a consequence the average pore size diameter increases (Table 4: $a, b, c, d$, and e). On the other hand, as the liquid phase content increases and its viscosity decreases, besides producing the reduction in the porosity of the tile bodies, the pre-existent capillary system is partially blocked (AMORÓS et al., 1992), which reduces the interconnected porosity even more. As a result of these two conflicting effects, curves (average pore radius vs. temperature) with the presence of a maximum can be observed (Figures 5 and 6). The reduction of porosity is linked to the increase in the mechanical resistance of the clayish matrix at the same time as the thermal expansion of the ceramic piece increases.

The increase seen in the average pore size radius of the ceramic piece with the reduction in porosity is more marked the less uniform the micro-structure of the raw piece is. From $1.000{ }^{\circ} \mathrm{C}$ upward in some pieces or from $1.050^{\circ} \mathrm{C}$ in others, high levels of sintering are reached,

TABLA 4 a) (TABLE 4 a)

Parámetros correspondientes a la serie FM

(Parameters corresponding to series FM)

\begin{tabular}{|c|c|c|c|c|c|c|c|}
\hline $\begin{array}{c}\mathbf{T} \\
(\mathbf{C})\end{array}$ & $\begin{array}{c}\mathbf{V}_{\mathbf{T}} \\
(\mathbf{m l} / \mathbf{g})\end{array}$ & $\begin{array}{c}\mathbf{S}_{\mathrm{T}} \\
\left(\mathrm{m}^{2} / \mathbf{g}\right)\end{array}$ & $\begin{array}{c}\varphi \\
(\mathbf{g} / \mathrm{ml})\end{array}$ & $\begin{array}{c}\varphi_{\text {ap }} \\
(\mathbf{g} / \mathrm{ml})\end{array}$ & $\boldsymbol{\epsilon}$ & $\begin{array}{c}\mathbf{K p . 1 0} \\
(\mathbf{m})\end{array}$ & $\begin{array}{c}\mathbf{r . 1 0} \\
(\mathbf{m})\end{array}$ \\
\hline 900 & 0,1580 & 5,462 & 1,8856 & 2,6854 & 0,2979 & 1,24 & 5,75 \\
\hline 950 & 0,1467 & 3,502 & 1,9181 & 2,6690 & 0,2813 & 2,46 & 8,37 \\
\hline 1.000 & 0,1345 & 1,928 & 1,9507 & 2,6444 & 0,2624 & 6,38 & 13,95 \\
\hline 1.050 & 0,1043 & 1,914 & 2,1051 & 2,6972 & 0,2195 & 3,26 & 10,90 \\
\hline 1.100 & 0,0584 & 1,334 & 2,2788 & 2,6285 & 0,1331 & 1,27 & 8,75 \\
\hline 1.150 & 0,0372 & 1,754 & 2,3521 & 2,5775 & 0,0875 & 0,20 & 4,24 \\
\hline
\end{tabular}


TABLA 4 b) (TABLE 4 b))

Parámetros correspondientes a la serie JT

(Parameters corresponding to series JT))

\begin{tabular}{|c|c|c|c|c|c|c|c|}
\hline $\begin{array}{c}\mathbf{T} \\
(\mathbf{C})\end{array}$ & $\begin{array}{c}\mathbf{V}_{\mathbf{T}} \\
(\mathbf{m l} / \mathbf{g})\end{array}$ & $\begin{array}{c}\mathbf{S}_{\mathbf{T}} \\
\left(\mathbf{m}^{\mathbf{2}} / \mathbf{g}\right)\end{array}$ & $\begin{array}{c}\varphi \\
(\mathbf{g} / \mathbf{m l})\end{array}$ & $\begin{array}{c}\boldsymbol{\varphi}_{\text {ap }} \\
(\mathbf{g} / \mathbf{m l})\end{array}$ & $\mathbf{\epsilon}$ & $\begin{array}{c}\mathbf{K p . 1 0} \\
(\mathbf{m})\end{array}$ & $\begin{array}{c}\mathbf{r . 1 6} \\
(\mathbf{m})\end{array}$ \\
\hline 900 & - & - & 1,7721 & 1,7784 & - & - & - \\
\hline 950 & 0,1864 & 3,477 & 1,7957 & 2,6993 & 0,3347 & 4,80 & 10,72 \\
\hline 1.000 & 0,1749 & 2,945 & 1,8470 & 2,7285 & 0,3230 & 5,70 & 11,88 \\
\hline 1.050 & 0,1496 & 1,839 & 1,9267 & 2,7070 & 0,2882 & 9,53 & $1, .27$ \\
\hline 1.100 & 0,1135 & 1,829 & 2,0475 & 2,6674 & 0,2323 & 4,47 & 12,41 \\
\hline 1.150 & 0,0689 & 4,871 & 2,1577 & 2,5346 & 0,1487 & 0,15 & 2, \\
\hline
\end{tabular}

TABLA 4 c) (TABLE $4 c)$ )

Parámetros correspondientes a la serie $\mathrm{CE}$

(Parameters corresponding to series $C E)$ )

\begin{tabular}{|c|c|c|c|c|c|c|c|}
\hline $\begin{array}{c}\mathbf{T} \\
(\mathbf{C})\end{array}$ & $\begin{array}{c}\mathbf{V}_{\mathbf{T}} \\
(\mathbf{m l} / \mathbf{g})\end{array}$ & $\begin{array}{c}\mathbf{S}_{\mathbf{T}} \\
\left(\mathbf{m}^{2} / \mathbf{g}\right)\end{array}$ & $\begin{array}{c}\boldsymbol{\varphi} \\
(\mathbf{g} / \mathbf{m l})\end{array}$ & $\begin{array}{c}\mathbf{\varphi}_{\text {qp }} \\
(\mathbf{g} / \mathbf{m l})\end{array}$ & $\boldsymbol{\epsilon}$ & $\begin{array}{c}\mathbf{K p . 1 0 ^ { - 1 6 }} \\
(\mathbf{m})\end{array}$ & $\begin{array}{c}\mathbf{r . 1 0 ^ { - 8 }} \\
(\mathbf{m})\end{array}$ \\
\hline 900 & 0,1859 & 4,724 & 1,7793 & 2,6589 & 0,3308 & 2,56 & 7,87 \\
\hline 950 & 0,1882 & 3,436 & 1,7729 & 2,6604 & 0,3336 & 4,99 & 10,95 \\
\hline 1.000 & 0,1738 & 2,961 & 1,8211 & 2,6646 & 0,3165 & 5,45 & 11,74 \\
\hline 1.050 & 0,1433 & 2,272 & 1,9202 & 2,6496 & 0,2752 & 5,47 & 12,61 \\
\hline 1.100 & 0,0940 & 2,441 & 2,0821 & 2,5889 & 0,1957 & 1,45 & 7,70 \\
\hline 1.150 & 0,0113 & 2,697 & 2,1112 & 2,1629 & 0,0285 & - & 0,84 \\
\hline
\end{tabular}

TABLA 4 d) (TABLE 4 d))

Parámetros correspondientes a la serie ZC

(Parameters corresponding to series $\mathrm{ZC})$ )

\begin{tabular}{|c|c|c|c|c|c|c|c|}
\hline $\begin{array}{c}\mathbf{T} \\
(\mathbf{C})\end{array}$ & $\begin{array}{c}\mathbf{V}_{\mathbf{T}} \\
(\mathbf{m l} / \mathbf{g})\end{array}$ & $\begin{array}{c}\mathbf{S}_{\mathbf{T}} \\
(\mathbf{m} / \mathbf{g})\end{array}$ & $\begin{array}{c}\varphi \\
(\mathbf{g} / \mathbf{m l})\end{array}$ & $\begin{array}{c}\boldsymbol{\varphi}_{\text {ap }} \\
(\mathbf{g} / \mathbf{m l})\end{array}$ & $\boldsymbol{\epsilon}$ & $\begin{array}{c}\mathbf{K p . 1 0} \\
(\mathbf{m})\end{array}$ & $\begin{array}{c}\mathbf{r . 1 0} \\
(\mathbf{m})\end{array}$ \\
\hline 900 & $0 ., 626$ & 2,905 & 1,8366 & 2,62050 & 0,4268 & 6,71 & 11,21 \\
\hline 950 & 0,1446 & 1,793 & 1,8895 & 2,6000 & 0,3759 & 12.22 & 16,13 \\
\hline 1.000 & 0,1414 & 2,024 & 1,9137 & 2,6235 & 0,3709 & 9,05 & 13,97 \\
\hline 1.050 & 0,1119 & 0,951 & 2,0159 & 2,6033 & 0,2913 & 20,17 & 23,54 \\
\hline 1.100 & 0,0810 & 0,844 & 2,1476 & 2,5999 & 0,2106 & 9,69 & 19,19 \\
\hline 1.150 & 0,0451 & 1,558 & 2,2643 & 2,5216 & 0,1156 & 0,48 & 5,78 \\
\hline
\end{tabular}


TABLA 4 e) (TABLE 4 e))

Parámetros correspondientes a la serie LA

(Parameters corresponding to series $L A)$ )

\begin{tabular}{|c|c|c|c|c|c|c|c|}
\hline $\begin{array}{c}\mathbf{T} \\
(\mathbf{C})\end{array}$ & $\begin{array}{c}\mathbf{V}_{\mathbf{T}} \\
(\mathbf{m} 1 / \mathbf{g})\end{array}$ & $\begin{array}{c}\mathbf{S}_{\mathbf{T}} \\
(\mathbf{m} 2 / \mathbf{g})\end{array}$ & $\begin{array}{c}\boldsymbol{\varphi} \\
(\mathbf{g} / \mathbf{m l})\end{array}$ & $\begin{array}{c}\boldsymbol{\varphi}_{\text {ap }} \\
(\mathrm{g} / \mathbf{m l})\end{array}$ & $\boldsymbol{\epsilon}$ & $\begin{array}{c}\mathbf{K p . 1 0}^{-16} \\
(\mathbf{m})\end{array}$ & $\begin{array}{c}\mathbf{r . 1 0} \\
(\mathbf{m})\end{array}$ \\
\hline 900 & 0,1518 & 2,732 & 1,8661 & 2,6036 & 0,3952 & 6,09 & 11,11 \\
\hline 950 & 0,1433 & 2,072 & 1,8946 & 2,6008 & 0,3727 & 8,91 & 13,83 \\
\hline 1.000 & 0,1105 & 1,793 & 2,0246 & 2,6008 & 0,2882 & 5,46 & $1, .32$ \\
\hline 1.050 & 0,0707 & 1,734 & 2,1815 & 2,5796 & 0,1823 & 1,51 & 8,16 \\
\hline 1.100 & 0,1301 & 2,180 & 1,9457 & 2,6050 & 0,3389 & 6,02 & 11,93 \\
\hline 1.150 & - & - & - & - & - & - & - \\
\hline
\end{tabular}

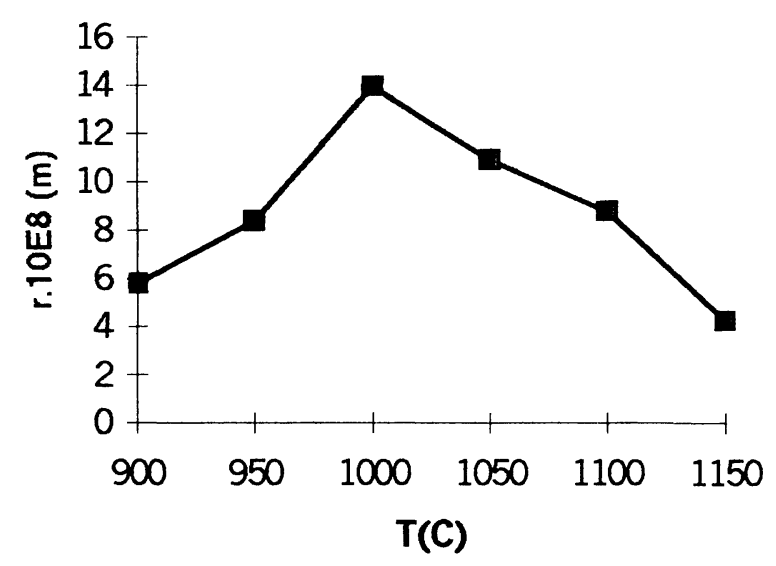

Figura 5.- Variación del radio medio de poro con la temperatura de cocción para la composición media de la serie FM.

Figure 5.- Variation in the average pore size radius ( $r$ ) with the firing temperature for an average composition series FM.

grados de sinterización elevados, este hecho se pone de manifiesto por una disminución brusca de la porosidad permeable.

Por lo que respecta a la densidad de las piezas (probetas cocidas) se observa un efecto normal de aumento progresivo de la misma al subir la tempertura de cocción, dado que con el incremento térmico se va completando la reacción de sinterización, junto con la disminución de la cantidad de poros por el mayor contenido en fase vítrea. El aumento de la densidad aparente del material ( $\varphi$ ap) es consecuencia de la reducción intensa de la porosidad abierta. A pesar de que se haya completado la reacción de sinterización, las posibles discrepancias pueden atribuirse a la gran cantidad de poros internos de diferentes tamaños que contiene el material.

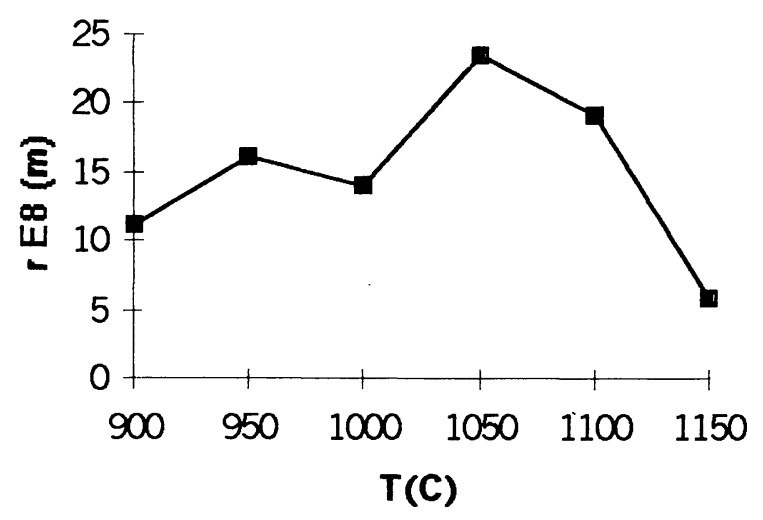

Figura 6.- Variación del radio medio de poro con la temperatura de cocción para la composición media de la serie ZC.

Figure 6.- Variation in the average pore size radius ( $r$ ) with the firing temperature for an average composition series $Z C$.

and this becomes evident with the brusque decrease in the permeable porosity.

As far as the density of the pieces is concerned fired ceramic bodies), we were able to observe a normal effect of progressive increase in the same as the firing temperature was increased, because the sintering reaction completes itself with the thermal increase, together with the decrease in the quantity of pores due to the greater vitreous phase content. The increase in the apparent density of the material $\left(\varphi_{a p}\right)$ is a result of the intensive reduction in open porosity. Even though the sintering reaction has been completed, the possible discrepancies can be attributed to the large number of different size internal pores that the material contains. 


\section{CONCLUSIONES}

Puede concluirse, en primer lugar, que es muy dificil predecir la resistencia mecánica en relación con la composición mineralógica de las materias primas y la dinámica mineral observada durante el proceso de cocción en las series de muestras estudiadas. Otros factores importantes a tener en cuenta en las propiedades mecánicas son la morfoscopia granular, la textura orientada de la masa de minerales y la cantidad y no homogeneidad de distribución de los poros.

Los valores obtenidos muestran un elevado nivel de dispersión, que hacen necesario llevar a cabo un alto número de determinaciones en cada ensayo. Las discrepancias que se observan son, en su mayoría, debidas a errores que dependen de la geometría de la pieza, de la existencia de micro-fisuras superficiales, así como de los errores derivados de los instrumentos de medida usados en los ensayos.

A la vista de los resultados obtenidos, se ha podido establecer que el módulo de resistencia mecánica a la flexión para cada una de las composiciones cocidas a $1.100^{\circ} \mathrm{C}$, se sítua en el intervalo correspondiente a materiales de revestimiento y pavimento cerámico (16$22 \mathrm{MPa}$ ), situándose lejos de las especificaciones del pavimento gresificado (34-35 $\mathrm{MPa})$.

La relación entre la porosidad y los parámetros que describen la textura porosa de los materiales cerámicos es complicada debido a la existencia de muchos poros con una compleja e irregular ordenación espacial y heterogénea distribución de formas y tamaños, que impiden su modelización a partir de los modelos propuestos en la literatura aunque permiten predecir un comportamiento general de aumento de resistencia mecánica con la disminución de la porosidad total de las piezas.

\section{AGRADECIMIENTOS}

Se agradece al profesor Dr. A. Boccaccini de la Universidad Técnica de Ilmenau, Alemania y al Dr. Jesús $\mathrm{M}^{\mathrm{a}}$ Rincón del Instituto E. Torroja (CSIC) sus valiosos comentarios y sugerencias.

\section{CONCLUSIONS}

All in all, it can be concluded that it is very difficult to predict mechanical resistance in relation to the mineralogical composition of the basic raw material and the mineral dynamics it shows during the firing process in the series studied. Other important factors come into play in this mechanical resistance, such as granular morphoscopy, oriented texture of the mass of minerals, and quantity and non-homogeneous distribution of the pores.

The values obtained show a high level of dispersion, which made it necessary to carry out a high number of determinations in each test. The discrepancies observed are in large part due to errors that depend on the geometry of the piece, on existent surface micro-fissures, as well as on errors derived from the device used in the tests.

In view of the values obtained, we can state that as far as the resistance to flexion obtained for each of the compositions fired at $1.100{ }^{\circ} \mathrm{C}$ is concerned, they can be situated within the interval for those materials used for pavements and/or floor coverings (16-22 MPa), somewhat inferior to the required specifications for earthenware (34-35 MPa).

The relation between porosity and the parameters that describe the porous texture of the ceramic tile bodies studied is complicated because of the fact that these have many pores with a complex and irregular spatial ordenation, with a broad distribution of forms and sizes, and as such they do not fit into established empirical equations.

\section{ACKNOWLEDGEMENS}

It is recognized valuable comments and suggerences from Dr. A. Boccaccini from Technical University of Ilmenau, Germany and Prof. Dr. Jesús $M^{\circ}$ Rincón from the Instituto Eduardo Torroja (CSIC).

\section{BIBLIOGRAFÍA}

(1) Amorós, J. L..; Beltrán, A.; Escardino, E.; Orts, M. J.: 1992. Permeabilidad al aire de soportes cocidos de pavimento cerámico. Bol. Soc. Esp. Ceram. Vidr., 31 (1992), 1, 33-35.

(2) Boccaccini, A. R.: 1994. Comment on dependence of ceramic fracture properties on porosity. Jounal of Materials Letters 13, $1035-1037$. (3) Chung, F. H.: 1974a. Quantitative interpretation of X-ray diffraction patterns of mixtures I. Matrix-flushing method for quantitative multicomponent analysis. J. Appl. Cryst.,7:519-525.

(4) Chung,F.H.: 1974b. Quantitative interpretation of X-ray diffraction patterns of mixtures II. Adiabatic principle of X-ray diffraction analysis of mixtures. J. Appl. Cryst., 7: 526-531. 
(5) Datta, S. K.: Mukhopadhyay, 1988. J. Mater. Sci. Lett., 7, 1119.

(6) Ellingson, W. A. 1987. Characterization of porosity in green-state and partially densified $\mathrm{Al}_{2} \mathrm{O}_{3}$ by nuclear magnetic resonance. Ceram. Eng. Sci. Proc., 8 (7-8) 503-512.

(7) Gualtieri, A.; Bertolani, M.: 1992. Mullite and Cristobalite formation in firing products starting from halloysitic clay. Applied Clay Science, 7,251-262.

(8) Jordán, M. M., Sanfeliu, T., De La Fuente, C. and Ballbe, E.: 1993. Ceramic Interest Weald Clays from Castellon. Third Euro-Ceramics 2,947-952. Faenza Editrice Iberica.

(9) Jordan, M. M, Boix, A., De la Fuente, C., Ballbe, E., Queralt, I. and Sanfeliu, T.: 1994. Mineralogía y propiedades cerámicas de arcillas cretácicas wealdienses de Castellón. Boletín de la Sociedad Española de Mineralogía, 17: pp. 135-143.

(10) Jordán, M. M.; Boix, A.; Sanfeliu, T. and De La Fuente, C.: 1995. The mineralogy of Cretaceous clays in Castellon and their application in the ceramic industry. International Ceramics Journal, 10:25-29. Faenza Editrice.

(11) Lorci , L.; Brusa, A.: 1991. Porous and vitrified single-fired tiles. Ceram. Eng. Sci. Proc. 12 (1-2) pp. 183-221.

(12)Lucarelli; L.; Venturi, V.: 1995. The mercury porosimeter: use in structural investigations of porcelain stoneware tiles. Ceramics: Charting the Future. Ed. Vicenzini. Techna Srl.

(13) Sanfeliu, T., De La Fuente, C., Jovani-Sales, M. and Alonso-Pascual1, J.J.: 1991. Aplicación de técnicas petrográficas en la caracterización de fabricados cerámicos. Anals do XXXV Congresso Brasilerio do Ceràmica e III Iberoamericano de Cerámica, Vidrio e Refractario.

(14) Wagh, A.S.; Singh, P.; Poepppel, R.B.. (1993). J. Mater. Sci. 28, 3589.

(1) Zweben, C.: 1991. Ceramic matrix composites mechanical properties and test methods. Ceram. Eng. Sci. Proc. 12 (1-2) pp. $409-503$.

\section{Publicaciones del Instituto Eduardo Torroja - CSIC}

\section{Número monográfico de MATERIALES DE CONSTRUCCIÓN}

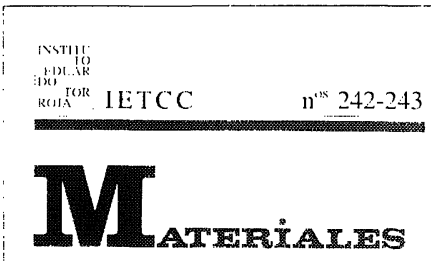

EI. VIDRIO EN LA CONSTRUCCIÓN

DE

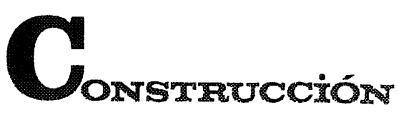

登

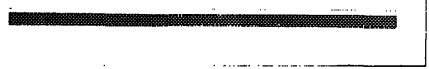

\section{EL VIDRIO EN LA} CONSTRUCCIÓN

$\left(n^{\text {os }} 242-243\right)$
- Procesos de alteración de las vidricras medievales. Estudio y tratamicntos de protección. (Alteration processes of medieval stained glass windows. Study and protection treatments). J. M ${ }^{a}$ Fernández Navarro.

- El efecto de la corrosión en vidrieras coloreadas.

(The effect of corrosion of stained glass windows).

J. Leissner.

- Formulación de vidrios absorbentes del calor. (Formulation of heat absorbing glasises). P. Álvarez-Casariego y P. Mazón.

- Dimensionamiento de placas de acristalamiento para edificios mediante un modelo probabilístico de rotura. (A probabilistic model for failure design of glass plates in building).

A. Fernández Canteli. I. Viña y A. Bernardo Sánchez.

- Caracterización de fibras en forma de laua de roca para aislamiento obtenidas a partir de basaltos camarios. (Characterization of fibers as rockwool for insulation obtained from canary islands basalts).

J. M. Cáceres, J. E. García Hernández y J. Mª Rincón.

- El GRC: Material compuesto de matriz inorgánica reforzado con fibras de vidrio AR.

(GRC: Composite material from an inorganic matrix reinforced with ar glass fibres).

P. I. Comino.

- Los materiales vitrocerámicos en la construcción.

(Cilass-ceramic as building materials).

J. Min Rincón y M. Romero.

- Gres porcelánico: Aplicaciones arquitectónicas, procesado y propiedades físico-mecámicas.

(Porcelainized stoneware: Architectural, processing and physico-mechanical properties).

T. Manfredini, M. Romagnoli y J. Mª Rincón.

Venta de ejemplares: distribución de Publicaciones Instituto de Ciencias de la Construcción Eduardo Torroja

c/Serrano Galvache, $s / n-28033$ Madrid

Tfrno..(91)302.04.40-Fax: (91)302.07.00 